\title{
Primary School Teachers' Conceptions about the Use of Robotics in Mathematics
}

\author{
María José Seckel ${ }^{1, * \mathbb{D}}$, Adriana Breda ${ }^{2}$, Vicenç Font ${ }^{2} \mathbb{D}$ and Claudia Vásquez ${ }^{3} \mathbb{D}$ \\ 1 Departament of Didactics, Universidad Católica de la Santísima Concepción, Alonso de Ribera, \\ Concepción 2850, Chile \\ 2 Departament of Linguistic and Literary Education, and Teaching and Learning of Experimental Sciences and \\ Mathematics, Universitat de Barcelona, Passeig de la Vall d'Hebron, 171, 08035 Barcelona, Spain; \\ adriana.breda@ub.edu (A.B.); vfont@ub.edu (V.F.) \\ 3 Departament of Mathematics, Campus Villarrica, Pontificia Universidad Católica de Chile, \\ Villarrica 4930445, Chile; cavasque@uc.cl \\ * Correspondence: mseckel@ucsc.cl
}

Citation: Seckel, M.J.; Breda, A.; Font, V.; Vásquez, C. Primary School Teachers' Conceptions about the Use of Robotics in Mathematics. Mathematics 2021, 9, 3186. https:/ / doi.org/10.3390/math9243186

Academic Editors: Jay Jahangiri and Michael Voskoglou

Received: 1 November 2021

Accepted: 7 December 2021

Published: 10 December 2021

Publisher's Note: MDPI stays neutral with regard to jurisdictional claims in published maps and institutional affiliations.

Copyright: (c) 2021 by the authors. Licensee MDPI, Basel, Switzerland. This article is an open access article distributed under the terms and conditions of the Creative Commons Attribution (CC BY) license (https:// creativecommons.org/licenses/by/ $4.0 /)$.

\begin{abstract}
Learning about the conceptions used by primary school teachers towards the use of robotics in class is essential as the first step towards its application in the classroom. Therefore, with the purpose of describing the understanding applied when teaching and learning mathematics use educational robots, research was conducted by means of mixed methods using a descriptive design by survey. Such research consisted of closed questions (Likert-type scale from 1 to 5) and open questions, given to 83 primary school teachers who currently teach students in the first years of school (First to Fourth grade) in two Chilean districts. The results showed that in general, there is a positive predisposition towards the addition of robots in the learning and teaching of mathematic processes during the first years of school, even though teachers claim there is a struggle to incorporate robots in their lessons due to the high number of students and the reduced space in their classrooms.
\end{abstract}

Keywords: math education; educational robotics; teachers' conceptions

\section{Introduction}

The agenda of general research related to the study of conceptions determines that such understandings are the ones which shape the meaning we give to things. This is because conceptions are formed from an individual perspective on the one hand, because of our own experiences, and on the other hand, from a social perspective as a result of the confrontation of our own elaborations with others [1].

Given the fact that teaching involves both personal and social perspectives, several studies have been carried out, focusing on investigating the teachers' conceptions, particularly the ones connected with teaching mathematics. With the intent of understanding the teachers' pedagogical methods and to know how they conceive teaching, many studies have been concerned with identifying their conceptions, not only about mathematics [2-5], but also about their teaching and learning processes [6-8]. In this view, several works have focused on identifying the teachers' conceptions of teaching different mathematical objects [9,10]; affective aspects of learning and class-design [2,11,12]; evaluation and competence [13]; teaching through the process of problem solving [14-19]; and the use of ICT resources [4,20-22].

In connection with the use of ICT resources, currently we can find research that seeks to study pedagogical practices and the teacher's conceptions in terms of the use of robots or to the development of computational thinking through robotics in classrooms [23-30]. Additionally, we can find examples of teachers' training in robotics [31], that focused on the STEM approach [32], as an active learning development [33]. Particularly, we can find research on the conceptions of the use of pedagogical robots at early ages [34-36]. 
Those studies show ambiguous results, because even though teachers value positively the use of robots in their classrooms, they also consider that the use of an educational robot may affect their perceptions and practices because it includes new knowledge and a change in the methodology of teaching and learning, different from the traditional ones. Specifically, the perception of teachers regarding the use of pedagogical robots during the early ages, in particular the use of Bee-bot $[34,35,37]$, is positive for the technical aspects and for the pedagogical and social aspects as well. However, they also point out that it presents difficulties and limitations.

Moreover, different trends and approaches regarding teachers' training, at their initial stages as well as throughout their careers, suggest that the research on and reflection of teachers' practices is a key strategy to improve teaching. Among the diverse theoretical approaches in mathematics, the Onto-Semiotic Approach (OSA) to cognition and mathematical instruction [38], suggests the Didactic Suitability Criteria (DSC) as a tool to organize the reflection of teachers' training, especially when such approach is focused on improving the teaching and learning processes of mathematics.

The DSC is a combination of six criteria, which break down in components and indicators that guide the improvement of implemented teaching processes. Said criteria (along with their components and indicators) can be inferred from the reflection of teachers' training on their personal or external teaching practices, even when there has been no development process to teach them. The DSC's components as well as their indicators have been proposed considering the current trends regarding the teaching of mathematics, the National Council of Teachers Mathematics' Principles [39] and the research's results in Didactics of Mathematics, which have an extensive consensus in the community.

The DSC is a multidimensional construct that consists of six partial criteria [40]: (1) epistemic facet criteria, to value whether if the math taught is "good math"; (2) cognitive facet criteria, to value prior to initiate the teaching process whether if what is intended to be taught is within a reasonable distance from what is already known by the students and, after the process, if the learnings accomplished are close to what was intended to be taught; (3) interactional facet criteria, to value if the interactions resolve the students' doubts and difficulties; (4) mediational facet criteria, to value the adaptation of the materials and temporal resources used through the training process; (5) affective facet criteria, to value the students' implications (interests and motivations) through the training process; and (6) ecological facet criteria, to value the adaptation to the educational training project, to the curricula guidelines and to the conditions of the socio-professional environment, among others. Each criterion breaks down into components and indicators (Table 1), which makes it possible for this construct to be useful to value the suitability of the teaching and learning processes of mathematics [41,42].

Table 1. Didactic suitability criteria and components.

\begin{tabular}{|c|c|}
\hline Suitability Criterion & Components \\
\hline Epistemic & $\begin{array}{l}\text { Errors, ambiguities, richness of processes, representativeness } \\
\text { of the complexity of the mathematical object }\end{array}$ \\
\hline Cognitive & $\begin{array}{l}\text { Prior knowledge, curricular adaptation to individual } \\
\text { differences, learning, high cognitive demand }\end{array}$ \\
\hline Interactional & $\begin{array}{c}\text { Teacher-student interaction, students' interaction, autonomy, } \\
\text { formative assessment }\end{array}$ \\
\hline Mediational & $\begin{array}{c}\text { Materials resources, number of students, class schedule and } \\
\text { conditions, time }\end{array}$ \\
\hline Affective & Interests and needs, attitudes, emotions \\
\hline Ecological & $\begin{array}{l}\text { Curriculum adaptation, intra- and interdisciplinary } \\
\text { connections, social and labor usefulness, didactic innovation }\end{array}$ \\
\hline
\end{tabular}

Various research have observed a phenomenon that repeats frequently: the components and indicators of the DSC proposed by the OAS function as regularities in the teachers' approach when they value an episode or justify that a didactics proposal signifies 
an improvement, without having been taught the usage of such tools to guide their reflection. That is to say, the teachers' comments can be considered as proof of the implicit use of any of the DSC components or indicators as a guide which must orientate the teachers' practice for a correct application [43]. We began this research by asking teachers who do not know about the didactic suitability criteria construct what they think of the incorporation of robots in the teaching and learning processes of mathematics. In a certain way, we put them in a position to reflect on a possible improvement of their teaching of mathematics, with the sole purpose of analyzing and organizing their statements applying the components and indicators of the DSC.

Breda, Font and Pino-Fan [44], explain this presence of DSC in the teachers' approach as having been taken from an existing consensus (from different origins) established among the community of mathematics' teachers regarding the aspects to be considered to accomplish a good math class. In contrast, whenever it is possible to determine a criterion that guides the teachers' practice, such criterion can be interpreted as a belief, if we understand it according to Peirce [45], and zero criterion as a disposition towards action. The group of criteria, also according to Peirce, can be understood as the teachers' conception. This way of understanding the conception as a group of criterions, is also considered by some investigators of the Didactics of Mathematics (i.e., [46,47]).

Therefore, one of the uses of DSC in the investigational field, is the consideration of the teachers' conceptions, assuming the premise that when consulting about the implementation of an innovation in the mathematics' teaching and learning processes, the teachers are faced with a situation of analysis, in which their conceptions are revealed and such conceptions are based implicitly in the DSC [40,43,48-51]. In that sense, in the present study it is intended to answer the following question: Which are the conceptions that primary school teachers have regarding the use of educational robots in the process of teaching and learning mathematics? This question is relevant in the context of the Chilean ministerial initiatives towards introducing Computational Thinking in the Math and Science syllabus. To answer the matter, the study has the objective to characterize teachers' conceptions on the use of robotics when teaching and learning mathematics during the early ages at school.

\section{Materials and Methods}

This study was conducted by means of a mixed methods approach and the methodology applied was an explorative-descriptive type [52]. A non-experimental research method design was followed, descriptive by means of a survey which was characterized by being the first approach to the phenomenon researched, providing general data of the population of interest [53].

\subsection{Participants}

The sample of participants consists of a probabilistic sampling, which represents the teachers from educational centers that have a practice agreement with a university from Maule's Region. Said sample was selected by means of a two-stage cluster sampling method with probabilities proportional to size. In the first stage, 30 different size sample institutions were obtained, and in the second stage, 2 out of 4 grades of those institutions were randomly selected, then the teachers of each of the grades obtained were selected. Therefore, the final sample consists of 83 teachers from First to Fourth grades of primary school in Chile (74 women and 9 men), who work at a public and a partially state subsidy school in Talca and Curicó districts (Chile). Among these participants, 19 have a masters' degree, 24 have a post-graduate degree in mathematics and 8 of them have a training course in robotics. Some of the participants have more of these academic formations (masters' degree and robotics training, masters' degree and post-graduate degree or post-graduate degree and robotics training). In terms of years of professional experience, 10 participants have at least 1 year of experience, 17 have between 1 and 3 years of experience and 56 have more than 3 years. 


\subsection{Instruments and Variables}

The instrument applied (see annex 1 in see Annex 1 in Supplementary Materials), used during the COVID-19 sanitary confinement during the year 2020, involved a total of 42 items (see details in Seckel, Breda and Font [54]) that were presented in two sections; the first one entailed closed questions ( 39 items) and the second one, open questions ( 3 items).

The validation process was conducted through the expert's judgement technique, in which 5 judges were involved, and had replied to an online validation survey. The items were evaluated through four parameters: clarity (the item is easily understood, that is to say, its semantics and syntaxis are correct), coherence (the item has a logic relation with the dimension or the parameter analyzed), relevance (the item is essential or important, that is to say, it must be included) and sufficiency (the items which belong to a same dimension are sufficient to obtain the extent of the dimension) [55]. The closed question items were evaluated considering the 4 parameters, whereas the open question items were evaluated through the parameters of clarity, coherence and relevance. The process of reviewing the questions handed out to the judges was conducted in two stages. In the first stage, the Content Validity Coefficient (CVC) was applied, by which it was able to measure the grade of agreement among the experts regarding the items and the instrument in general. Once the coefficients have been obtained, their values were analyzed according to the scales: unacceptable (CVC minor to 0.60), deficient (CVC major or equal to 0.60 and minor or equal to 0.70 ), acceptable (CVC major to 0.71 ) and minor or equal to 0.80 ), good (CVC major to 0.80 and minor or equal to 0.90 ) and excellent (CVC major than 0.90) [52]. In the second stage, the relevance to retain those items that had accomplished a CVC major to 0.71 and minor or equal to 0.80 (validity and acceptable concordance) was analyzed according to the expert's recommendations. Moreover, in this stage, the instrument was revised and corrected following the experts' suggestions, according to four scopes: [53] (i) appropriate use of words, (ii) adequacy of the questions' meaning so that they can quantify only one objective, (iii) adding an item to increase the adequacy of a specific dimension. Therefore, the instrument evaluated obtained a validity coefficient of 0.88 .

The first section considered a Likert-type scale from 1 to 5 ( 1 completely disagree and 5 completely agree, 3 neither agree nor disagree as a middle point) with 39 affirmations about the learning and teaching with robots (which will be referred as to dimensions from now on) and articulated based on DSC (epistemic, cognitive, interactional, mediational, affective, ecological), its components and indicators (Table 1).

The teaching dimension considers 21 affirmations or items referring to the impact of the use of pedagogical robots when teaching mathematics, whereas the learning dimension comprises the subsequent 18 items related to the learning of mathematics by using robots as a pedagogical resource. Moreover, these affirmations are grouped according to the didactic suitability criteria that have been taken as a foundation for its reasoning, as shown in Table 2.

Initially, the participants' conceptions were inferred from the annex of closed questions considering 2 variables: the first one is the known dimension (teaching dimension and learning dimension), and the second one is the didactic suitability criterion, which is reflected in their score of each affirmation.

Furthermore, in terms of personal and professional characteristics of the participants, the following information was collected: gender $(1=$ woman; $0=$ man $)$, academic formation (postgraduate degree in math or initial degree, master's degree and/or training in robotics) and classroom experience $(1=$ less than a year; $2=$ between one year and three; $3=$ more than three). As mentioned before, in reference to the variable of the academic formation, it must be pointed out that the formation options are not limited - a participant may have answered more than one option (i.e., masters' degree and robotics training, masters' degree and post-graduate degree or post-graduate degree and robotics training).

The second section considered three open questions, which were supposed to be answered after watching a video in which the Blue-Bot robot was presented along with its programming functions. In the first open question, a math assignment was introduced 
with the following query: "What suggestions would you provide to the teacher to address the start, development and ending of the class?". Then, the following questions were introduced: "What benefits would have the use of the pedagogical robot during a math class?" "What difficulties might be experienced while using the pedagogical robot during a math class?".

Table 2. Items distribution according to dimension and didactic suitability criterion.

\begin{tabular}{ccc}
\hline Dimension & $\begin{array}{c}\text { Didactic Suitability } \\
\text { Criterion }\end{array}$ & Items \\
& Epistemic & $1,2,3,4,5,6,7,8,9$ and 10 \\
& Cognitive & 11 and 12 \\
Teaching & Interactional & 13 and 14 \\
& Mediational & 15,16 and 17 \\
& Affective & 18 and 19 \\
& Ecological & 20 and 21 \\
\hline \multirow{2}{*}{ Learning } & Epistemic & $22,23,24,25,26$ and 27 \\
& Cognitive & 28 and 29 \\
& Interactional & 30 and 31 \\
& Mediational & 32 and 33 \\
& Affective & 34,35 and 36 \\
& Ecological & 37,38 and 39 \\
\hline
\end{tabular}

\subsection{Results Analysis}

The analysis of the data collected followed a quantitative validity model; the qualitative data support the quantitative validity [56]. Therefore, the survey's quantitative data were analyzed first, and then the qualitative data. Finally, the quantitative data were validated with the qualitative data.

In the quantitative study, different strategies of analysis were conducted. At first, the interest was focused on identifying professional profiles similarly enough to define a homogenous group internally but them being externally heterogenous. To do so, a group analysis or hierarchical cluster was conducted through the Ward group method, with the Euclidean distance squared as the measure of proximity among the groups or clusters. For the identification of the groups, we used the Ward's linkage dendrogram with a maximum distance of around 5. Once the clusters or groups were established, the next step was to explore the distribution (in terms of center, position, and dispersion) of the participants item's scores regarding the impact of the use of pedagogical robots in the mathematics learning and teaching processes according to the different didactic suitability criterions (Table 3), thus inferring the participants' conceptions. Finally, a descriptive analysis was carried out in terms of the grade of relation between the experience or previous academic formation and the participants' conceptions according to the different professional profiles established. Therefore, the statistics test or Pearson's chi-squared test is used, which allows to contrast the independence hypothesis in a contingency table, among qualitative variables. Moreover, said results are complemented with the force estimation association as of the Spearman's rank correlation coefficient. This measure sets between -1 and 1 and allows to conclude in a larger grade of association if the value is near the extremes $(-1$ negative relation and 1 positive) or lesser in cases where the value is nearly 0 .

The qualitative data were analyzed through the content analysis method [57]; therefore, the didactic suitability criterion was defined as the theoretical reference from which the participants' discourse was analyzed. Said criterion was also considered in the design of the closed-questions survey. Consequently, once the data were collected, the following occurred: (1) the content corpus was set up; (2) the categorization of the units' analysis took place; (3) the relation between the qualitative and quantitative analysis was determined. Moreover, to secure the validity of the qualitative data the study considered the regulatory dependence criterion [58], that consists of a control process of the data inter- 
pretation made by a group of examinators composed of a national collaborator and two international collaborators.

Table 3. Frequency (percentage) of participants according to the variables analyzed within each cluster.

\begin{tabular}{ccccc}
\hline Characteristic & Variable & Cluster 1 & Cluster 2 & Cluster 3 \\
\hline Gender & Woman & $47(87.0 \%)$ & $18(94.7 \%)$ & $9(90.0 \%)$ \\
\hline \multirow{2}{*}{ Academic } & Postgraduate & $15(27.8 \%)$ & $6(31.6 \%)$ & $3(30.0 \%)$ \\
formation & Master's & $8(14.8)$ & $2(10.5 \%)$ & $9(90.0 \%)$ \\
& Course & $6(11.1 \%)$ & $2(10.5 \%)$ & $0(0.0 \%)$ \\
\hline Years of & Less than 1 year & $5(9.3 \%)$ & $4(21.1 \%)$ & $1(10.0 \%)$ \\
previous & Between 1 and 3 years & $16(29.6 \%)$ & $0(0.0 \%)$ & $1(10.0 \%)$ \\
experience & More than 3 years & $33(61.1 \%)$ & $15(78.9 \%)$ & $8(80.0 \%)$ \\
\hline \multirow{2}{*}{ Grades of } & First & $37(68.5 \%$ & $14(73.7 \%)$ & $8(80.0 \%)$ \\
previous & Second & $39(72.2 \%)$ & $11(57.9 \%)$ & $7(70.0 \%)$ \\
experience & Third & $34(63.0 \%)$ & $11(57.9 \%)$ & $6(60.0 \%)$ \\
& Fourth & $30(55.6 \%)$ & $15(78.9 \%)$ & $4(40.0 \%)$ \\
\hline
\end{tabular}

\section{Results}

\subsection{Quantitative Study}

\subsubsection{Participants' Professional Profiles}

Through the group analysis, three groups or clusters of participants were identified who had similar experience or academic formation as well as shared the concepts of using pedagogical robots in the learning and teaching mathematics. The first cluster was formed by 54 participants $(65.1 \%)$ whereas the second one was by 19 participants $(22.9 \%)$ and the third by 10 participants $(12.0 \%)$. In Table 3, some of the personal and professional characteristics are exhibited in relation to the participants' previous experience and academic formation, pursuant to the three identified clusters.

As for Cluster 1, formed by 54 participants, among them $87 \%$ were women, who mainly have a postgraduate degree in Math, even though they do not exceed the $28 \%$ of the teachers, whereas those with an introductory course in robotics are the least frequent variable. In terms of previous experience, most of the participants (61.1\%) have more than 3 years of practice, focused on the first grade's education $(72.2 \%$ for second grade and $68.5 \%$ for first grade).

In Cluster 2, only 1 person is a man out of the 19 participants (94.7\% women), and likewise with the above-mentioned case, most of the participants have a postgraduate degree in Math, and do not exceed a third of the grand total of the teachers in this group (31.6\%). As for the years of experience in the classroom, $78.9 \%$ of the participants have been teaching for more than 3 years, whereas $21.1 \%$ do not surpasses the first year of practice. Moreover, this previous experience focused mainly on the fourth and first grades $(78.9 \%$ fourth grade and $73.7 \%$ first).

Finally, in Cluster 3 again women are predominant, (90\%) amongst the 10 participants of this group, who in the majority have a master's degree (90\%) none of them have taken an introductory training course in robotics for teaching. As for the previous experience, $80 \%$ of the participants have been teaching for more than 3 years at primary level, mainly at first and second grades ( 80 and $70 \%$, respectively).

\subsubsection{Participants' Conceptions}

In this section we explore the results through a double-entry table where the measures of centralization and dispersion of the scores related to the first variable (teaching/learning) are shown in the columns; and in the rows scores related to the didactic suitability criterion. The results obtained are shown in Table 4. 
Table 4. Statistics of the participants' scores.

\begin{tabular}{ccccccc}
\hline Didactic & \multicolumn{3}{c}{ Teaching Dimension } & \multicolumn{3}{c}{ Learning Dimension } \\
\cline { 2 - 7 } $\begin{array}{c}\text { Suitability } \\
\text { Criteria }\end{array}$ & $\mathbf{A}$ & $\mathbf{S D}$ & $\mathbf{P} \%$ & $\mathbf{A}$ & $\mathbf{S D}$ & $\mathbf{P \%}$ \\
\hline Epistemic & 4.3 & 0.81 & $\mathrm{P}_{10}=3.2$ & 4.4 & 0.74 & $\mathrm{P}_{10}=3.5$ \\
Cognitive & 4.4 & 0.86 & $\mathrm{P}_{10}=3.0$ & 4.5 & 0.77 & $\mathrm{P}_{10}=3.5$ \\
Interactional & 4.4 & 0.88 & $\mathrm{P}_{10}=3.0$ & 4.4 & 0.76 & $\mathrm{P}_{10}=3.0$ \\
Mediational & 3.5 & 1.06 & $\mathrm{P}_{30}=3.0$ & 4.4 & 0.78 & $\mathrm{P}_{10}=3.0$ \\
Affective & 4.4 & 0.75 & $\mathrm{P}_{10}=3.5$ & 4.5 & 0.72 & $\mathrm{P}_{10}=3.7$ \\
Ecological & 4.2 & 0.85 & $\mathrm{P}_{10}=3.0$ & 4.6 & 0.70 & $\mathrm{P}_{10}=4.0$ \\
\hline Global & 4.2 & 0.74 & $\mathrm{P}_{10}=3.1$ & 4.5 & 0.66 & $\mathrm{P}_{10}=3.6$ \\
\hline
\end{tabular}

A (average); SD (standard deviation); $\mathrm{P} \%$ percentile.

Globally, the average scores of the participants were bigger towards the learning of mathematics with robots (4.5 points), but in both cases greater than the indifference position. On the other hand, in reference to didactic suitability criteria, we noticed that in the first variable, in teaching as well as in learning, the average scores surpassed the three points of indifference. Nevertheless, the mediational didactic suitability criterion presented a bigger variation between both dimensions, with more than one point of difference from the average score, being the lowest towards teaching. Hence, it can be inferred that among the participants there is a favorable conception towards the incorporation of robot in the mathematics' learning and teaching processes. This means that the participants have a conception with certain balance for the value on the advantages represented by the incorporation of robots (mathematics that facilitates relevant processes such as generalization and pattern guesswork, better motivation for students, better learning, among others) even though the aspect the participants see as the less beneficial is related to the mediational didactic suitability criterion.

Later, it was analyzed further on the results according to the three groups or clusters previously detailed (Table 3), and said results are presented in Table 5.

Table 5. Average score of the participants according to their cluster.

\begin{tabular}{|c|c|c|c|c|c|c|c|c|c|c|c|c|}
\hline \multirow{3}{*}{$\begin{array}{l}\text { Didactic } \\
\text { Suitability } \\
\text { Criteria }\end{array}$} & \multicolumn{4}{|c|}{ Cluster 1} & \multicolumn{4}{|c|}{ Cluster 2} & \multicolumn{4}{|c|}{ Cluster 3} \\
\hline & \multicolumn{2}{|c|}{ Teaching } & \multicolumn{2}{|c|}{ Learning } & \multicolumn{2}{|c|}{ Teaching } & \multicolumn{2}{|c|}{ Learning } & \multicolumn{2}{|c|}{ Teaching } & \multicolumn{2}{|c|}{ Learning } \\
\hline & $\mathbf{A}$ & SD & $\mathbf{A}$ & SD & $\mathbf{A}$ & SD & A & SD & $\mathbf{A}$ & SD & $\mathbf{A}$ & SD \\
\hline Epistemic & 4.7 & 0.32 & 4.9 & 0.22 & 4.0 & 0.50 & 4.0 & 0.30 & 2.7 & 0.82 & 3.0 & 0.78 \\
\hline Cognitive & 4.8 & 0.46 & 4.9 & 0.28 & 4.3 & 0.45 & 4.2 & 0.48 & 2.7 & 0.98 & 3.0 & 0.86 \\
\hline Interactional & 4.8 & 0.38 & 4.8 & 0.44 & 4.1 & 0.64 & 4.1 & 0.50 & 2.7 & 0.88 & 3.2 & 0.94 \\
\hline Mediational & 3.9 & 0.98 & 4.6 & 0.62 & 3.0 & 0.66 & 4.4 & 0.53 & 2.3 & 0.69 & 3.2 & 0.95 \\
\hline Affective & 4.8 & 0.31 & 4.8 & 0.32 & 4.1 & 0.40 & 4.3 & 0.44 & 3.0 & 0.80 & 3.1 & 0.90 \\
\hline Ecological & 4.5 & 0.60 & 4.9 & 0.17 & 3.9 & 0.57 & 4.3 & 0.44 & 2.8 & 0.92 & 3.3 & 1.07 \\
\hline
\end{tabular}

A (average); SD (standard deviation).

Table 5 shows that in Cluster 1, the scores were positive in every one of the criteria according to both dimensions (teaching and learning), even though slightly minor regarding teaching mathematics. Furthermore, in the latter, the mediational didactic suitability criterion was the lowest average score (3.9 points) regardless being above the indifference position. In Cluster 2, the scores were also positive, but less intense than in the previous group. In this case, the greater differences among the score in regards both dimensions were collected in the mediational criterion, showing an indifference position in terms of the adequation of robotic material resources for teaching mathematics (3.0 points); however, it was positive in terms of learning (4.4 points). In Cluster 3, the scores were in general negative or indifferent regarding teaching and learning mathematics with the use of pedagogical robots. Additionally, as well as in the other cases, the criterion with less average score was the mediational in the teaching mathematics with the use of robots ( 2.3 points). 
When grouping the participants in clusters, it could be observed that the favorable conception of incorporation robots in the mathematics learning and teaching process varies accordingly to the group. It can be noted that the first cluster is more favorable and the third is not.

\subsubsection{Relation between Conceptions and Experience or Previous Academic Formation}

In order to analyze the relation between the conceptions of the use of robots in mathematics teaching and learning process and some of the variables related to the experience and previous academic formation of the participants, it is necessary to redefine some of the variables. From the global results (Table 4), we noticed that participants gave, in general, positive scores to the affirmations to both dimensions analyzed, teaching and learning mathematics with the use of robots. This allowed us to infer on conceptions that entails positive dispositions towards the incorporation of the robots in the learning and teaching of mathematics, also towards the advantages of the use of robots for learning mathematics. However, the results in Clusters 2 and 3 reflected some cases in which the disposition was less positive or even negative. Thus, to analyze the average scores in each of the study's dimensions, a qualitative criterion was defined in regards the intensity of the results and it is differentiated between the positive conceptions (average score less than 4.5) and very positive (average score more or equal to 4.5).

Additionally, considering the also qualitative nature of the collected variables on the academic formation (if each participant has (1) or has not (0) a postgraduate degree, master's, or course) and the experience (less than a year (1), between one and three (2), or more than three (3)) we used the independent chi-squared test. The contingency tables used in each case are presented in Tables 6 and 7, together with the $p$-value of the independence test and the Spearman's rank correlation coefficient.

Table 6. Frequency of the participants according to the crossed analysis between the conceptions and academic formation.

\begin{tabular}{|c|c|c|c|c|c|c|c|c|}
\hline Dimension & \multicolumn{2}{|c|}{ Variable } & Positive & Very Positive & Chi-Squared & g.1. & $p$-Value & Correlation \\
\hline \multirow{6}{*}{$\begin{array}{l}\text { Teaching } \\
\text { conceptions }\end{array}$} & \multirow{2}{*}{$\begin{array}{l}\text { Postgraduate } \\
\text { degree }\end{array}$} & Yes & 11 & 13 & \multirow{2}{*}{1.601} & \multirow{2}{*}{1} & \multirow{2}{*}{0.206} & \multirow{2}{*}{0.139} \\
\hline & & No & 36 & 23 & & & & \\
\hline & \multirow{2}{*}{$\begin{array}{l}\text { Master's } \\
\text { degree }\end{array}$} & Yes & 6 & 5 & \multirow{2}{*}{0.022} & \multirow{2}{*}{1} & \multirow{2}{*}{0.881} & \multirow{2}{*}{0.016} \\
\hline & & No & 41 & 31 & & & & \\
\hline & \multirow{2}{*}{ Courses } & Yes & 4 & 4 & \multirow{2}{*}{0.158} & \multirow{2}{*}{1} & \multirow{2}{*}{0.691} & \multirow{2}{*}{0.044} \\
\hline & & $\mathrm{No}$ & 43 & 32 & & & & \\
\hline \multirow{6}{*}{$\begin{array}{l}\text { Learning } \\
\text { conceptions }\end{array}$} & \multirow{2}{*}{$\begin{array}{l}\text { Postgraduate } \\
\text { degree }\end{array}$} & Yes & 8 & 16 & \multirow{2}{*}{0.002} & \multirow{2}{*}{1} & \multirow{2}{*}{0.961} & \multirow{2}{*}{0.005} \\
\hline & & $\mathrm{No}$ & 20 & 39 & & & & \\
\hline & \multirow{2}{*}{$\begin{array}{l}\text { Master's } \\
\text { degree }\end{array}$} & Yes & 3 & 8 & \multirow{2}{*}{0.237} & \multirow{2}{*}{1} & \multirow{2}{*}{0.626} & \multirow{2}{*}{0.053} \\
\hline & & No & 25 & 47 & & & & \\
\hline & \multirow[t]{2}{*}{ Courses } & $\mathrm{Si}$ & 1 & 7 & 1.786 & 1 & 0.181 & 0.147 \\
\hline & & No & 27 & 48 & & & & \\
\hline
\end{tabular}

Table 7. Frequency (percentage) of the participants according to the crossed analysis between the conceptions and the previous experience.

\begin{tabular}{|c|c|c|c|c|c|c|c|c|}
\hline \multirow{2}{*}{ Dimensions } & \multirow{2}{*}{ Variable } & \multicolumn{3}{|c|}{ Years } & \multirow{2}{*}{ Square-Chi } & \multirow{2}{*}{ g.1 } & \multirow{2}{*}{$p$-Value } & \multirow{2}{*}{ Correlation } \\
\hline & & $<1$ & $1-3$ & $>3$ & & & & \\
\hline \multirow{2}{*}{ Teaching conceptions } & Positive & 5 & 7 & 35 & 2.618 & 2 & & \\
\hline & Very positive & 5 & 10 & 21 & & & 0.270 & -0.153 \\
\hline \multirow{2}{*}{ Learning conceptions } & Positive & 5 & 2 & 21 & 5.209 & 2 & & \\
\hline & Very positive & 5 & 15 & 35 & & & 0.074 & -0.068 \\
\hline
\end{tabular}


For the interpretation of the data present in Table 6, it is necessary to consider that a participant could have declared academic formation in more than one of the variables, or else could have declare dnot having any of them.

The empiric results (Tables 6 and 7) show that there is not enough evidence in the sample to reject the hypothesis of independence between the academic formation and the previous experience, and the conceptions of the participants regarding the use of robots in learning and teaching mathematics (see $p$-values in both tables, all of them greater than the level of significance assumed at 0.05). As for the academic formation, the conceptions regarding teaching are closely related (although slightly) to the fact of having or not a post graduate degree in mathematics (correlation of 0.139), whereas the conceptions of learning are related to the specialization courses of robotics (correlation of 0.147). Furthermore, in terms of the years of experience, the association is stronger, although negative ( -0.153 correlation) as the conceptions regarding teaching were positive, the participants' professional experience was lower. In the case of learning, which was also negative, the association was not so strong.

\subsection{Qualitative Study}

Below, we present the analysis of the open questions, broken down by questions and evidence of the participants' discourse will be presented (P1, P2, P3, .. , Pi " $\mathrm{i}$ " stands for the code assigned for each of the participants).

The process of categorization of the analyzed units showed evidence of suggested actions in the participants' discourses that derived implicitly from any of the didactic suitability criterion (or from some of their components or indicators).

In Figure 1, the results obtained from the first open question "What suggestions would you provide to the teacher to address the start, development and ending of the class?" are stated.

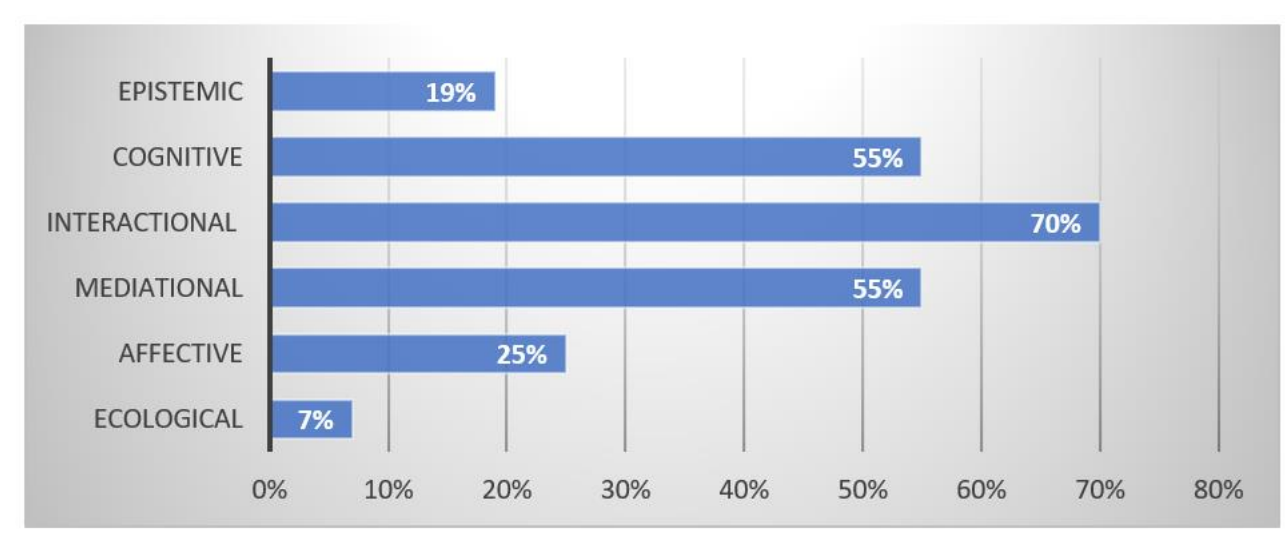

Figure 1. Suggestions regarding the implementation of a math assignment with the use of the Blue-Bot Robot.

As it can be inferred from Figure 1, the criterion that gathers much of the percentage analyzed units is the "interactional" one, that encloses a $70 \%$ of the action recommendations given by the participants for the implementation of the assignment. Such recommendations are mainly focused on the teacher-student interaction. Furthermore, some examples of the analyzed units related to this criterion:

P13: Introduce questions connected with pattern sequences and perform an activity with the classroom in which the students must follow patterns.

P44: Using the work of the students randomly picked out and through guided questions, make a summary of the work performed in class.

P70: Consider every idea given by the children, even if they are not correct. Let there be communication.

P67: The teacher explains how to move Blue-Bot, with clear and concise instructions. 
P81: It will be observed if it (the robot) made all the respective stops in each flower; if not, then some questions will be made in order to identify their errors and be able to correct them.

Additionally, the cognitive and mediational criteria have also obtained a high percentage (55\% in each) in the participants' discourse. In terms of the cognitive criterion, it can be observed that the analysis units are focused on producing actions that allow the recognition from the students of their previous knowledge, this can be observed in the following examples:

P15: For the start, I would find out what the students know about the objective and by asking them questions inquire into their knowledge.

P24: Be clear that the students know the patterns and sequences.

P67: Activate previous knowledge regarding the use of the math robot.

P71: At the beginning, I conducted a brainstorm of the concepts to work on.

P79: Activated previous knowledge on the use of patterns. The students can explain the pattern of simpler activities.

In the mediational criterion, the analyzed units are focused on the use of additional resources beyond the use of the robot, the classroom's conditions (physical space and number of students) and time management, as evidenced in the following examples:

P41: Show them a video to activate the previous knowledge.

P49: A video is introduced along with a similar activity for the students to know the use of the robot.

P7: To address the class's objective properly, I would recommend my colleague to consider the space defined for the activity $(\ldots)$.

P16: represent other paths in the classroom.

P30: For starting, I would recommend giving the students some time to observe the image (...).

Regarding the emotional criterion, the participants made comments on actions that can motivate the students, i.e.:

P4: Perform a pattern recreational activity, for example, create rhythmic patterns with applauses.

P13: Additionally, they can jump and move forward from flower to flower imagining they are the bee.

P22: Conduct an adequate motivation to challenge them to work in class.

P76: At the beginning of the class, I would recommend doing a game based on the exercise of the students being the bee and where they must move accordingly to the images in the classroom floor and where they'll have to count how many jumps they have performed in order to reach one place or the other.

Regarding the epistemic criterion, most of the comments highlighted the fact that the use of Blue-Bot would improve the generalization and formulation of guesswork.

P3: Show them different patterns through the robot; show them how it identifies, show them the images of the flower and the bee so that the students can position the robot in each of the images, and then they will name the pattern that the robot followed to pass through each image and the rest of the students can guess the formed pattern, i.e., flower, bee, flower, bee.

P13: Use the educational robot that moves from the bee towards each of the flowers, where the student will have to identify the pattern followed by the robot.

P22: I consider the importance of the modelling, step by step in real time (about $7 \mathrm{~min}$ ).

P34: I would recommend the development of group thinking about the instructions created, which could be discussed later where the students can communicate and argue about their experience during the activity.

P37: For the ending, the students should state the different alternatives of the patterns that they used in order to solve each of the given situations, modelling and reasoning their choices. 
Regarding the ecological criterion, there were less comments than those reported in the other criteria; nevertheless, they are relevant since they suggest connecting the robot's activity with other topics, i.e., studying bees and pollination.

P31: Comment on the bees' characteristics and their pollination process.

P68: It cannot be overlooked the importance of coordinating with other syllabus, using the bee activity with Natural Sciences and the importance of using them for our planet.

P84: Before presenting the activity, it would be important to associate it with the science class and the patterns observed, giving emphasis with the bees' life (extracts from the movie Bee Movie could be used, where patterns of the bees' conducts are shown).

Alternatively, in Figure 2 the benefits that would derive from performing activities that allow the introduction of robots in the mathematics' teaching and learning process are noted; acknowledged in the teachers' discourse when replying to the question of "What benefits would have the use of the pedagogical robot during a math class?".

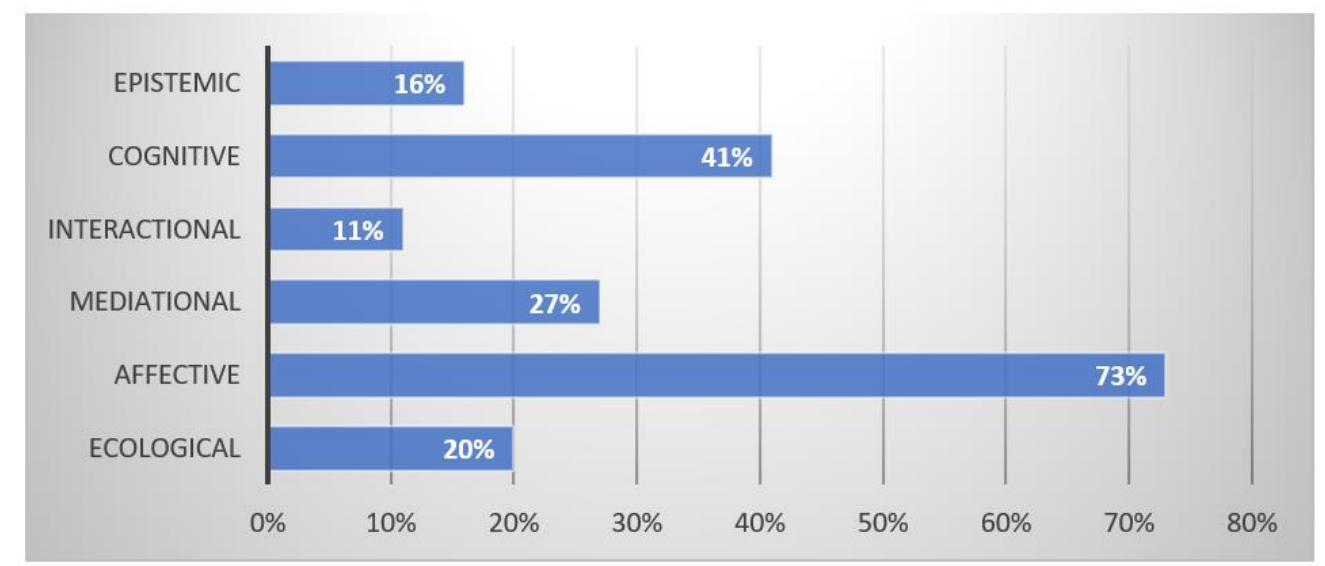

Figure 2. Benefits of using Blue-Bot robot during a math class.

In Figure 2, it can be observed that the affective suitability didactic criterion is the one that had more mentions in the analyzed units, followed by the cognitive criterion. As for the analyzed units related to the affective criterion, we observed that they relate primarily with the students' needs and interests:

P3: The benefit would be the motivation towards the classes, a very much active learning by the children, participatory, where they can learn through games and technology, which is what nowadays motivates them the most.

P48: I think that the pedagogical robot would help a lot in my classes because students would be more motivated.

P79: To learn through games makes learning much more amicable.

In turn, the analyzed units related to the cognitive criterion are mainly related to the benefits of the use of the robot to enhance the mathematical learning (learning component of this criterion):

P2: All those related to cognitive development in a whole range of possibilities that comprise mathematical skills.

P47: Learning through errors and realizing mathematical concepts.

P83: It is a rich learning process, cerebrally speaking, because the logical actions provoked in the children does not happen through the traditional process of learning mathematics.

Even though most of the benefits are related to the affective and cognitive suitability criteria, the other criteria: mediational, ecological, interactional and epistemic, respectively, are also valued as for their benefits.

P46: It would be a definite, visual, motivational means of interaction, worked through trial-and-error. The game is introduced; it gathers the group within the class.

P48: It would be an innovative tool, something that will catch their attention because it is not a common element in class. 
P70: The conversation (interaction) and the recollection of ideas will be the elements which will solve the problem presented.

P40: It would be a powerful tool to develop mathematical skills in my students.

Finally, in Figure 3, the difficulties that would derive from conducting actions that would allow the introduction of robots in the mathematics learning and teaching process are presented, observed in the teacher's discourses as a result of the question: "What difficulties might be experienced while using the pedagogical robot during a math class?".

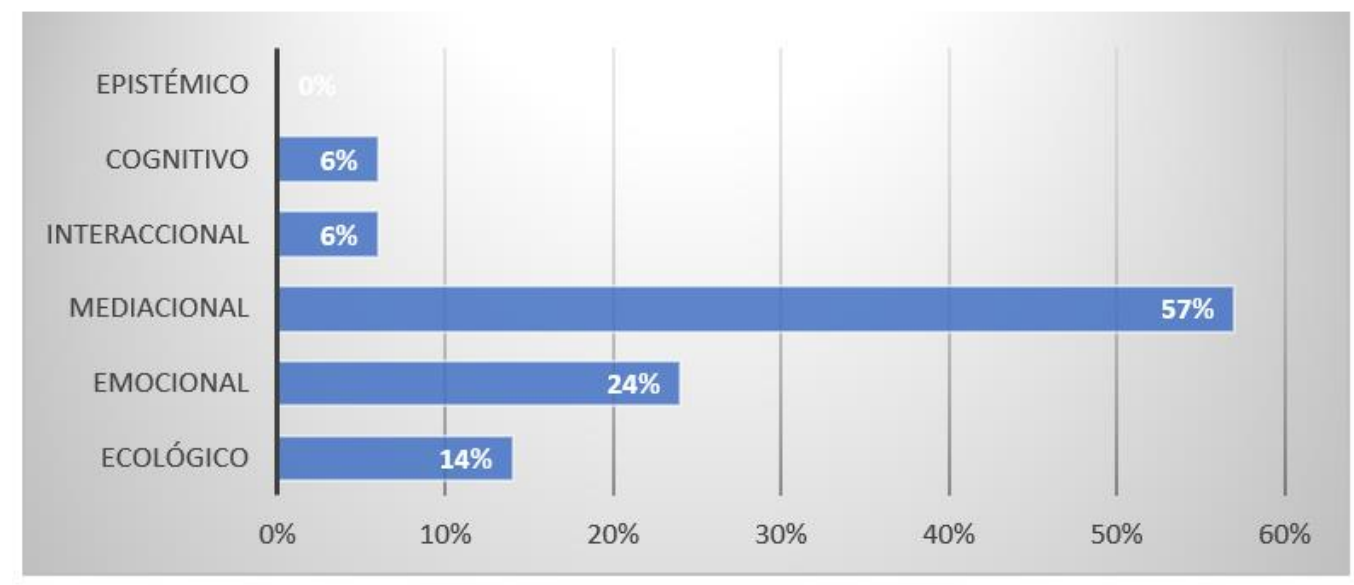

Figure 3. Difficulties that might be experienced while using the Blue-Bot robot during a math class.

As for the difficulties, in general terms it is observed that the units analyzed focused on the teaching dimension, mainly in the mediational criterion with a $57 \%$. In said criterion, it is evidenced that the analyzed units aim their discourse primarily towards the number of students and the space of the classroom, as exemplified below:

P12: I think that the main difficulty manifests in terms of the number of students per classroom and the little (or no) space in which we must develop the playful activities that imply teamwork.

P19: The problem would be that due to the great number of students in the classroom, the development of the class would be complicated. Not every student would be able to manipulate it. Moreover, we do not have enough room to use it.

P46: The room in my classroom is small: I have 23 students, and the teacher and assistant interact in the same space.

P56: The biggest difficulty is the big number of the class and the little room inside the classroom to perform the work.

P60: The number of students is high for just one person in charge of said group of people. Additionally, it would be ideal to have a special area designed for this type of robotic classroom.

Even though most of the difficulties are related to the mediational suitability criteria, other difficulties associated with the rest of the criteria are valued, except for the epistemic criterion. Next, we present some of the comments related to the affective, ecological, cognitive, and interactional criteria, respectively.

P70: That the students are not motivated to learn.

P22: The teacher's preparation in regards this type of resource and maybe the costs of its introduction.

P52: Maybe the handling of the robot is not as understandable to everyone.

P79: Not giving the instructions clearly enough may cause conflict among the students; nevertheless, this will depend on the group management and the clarity of the explanation from the teacher in charge. 


\subsection{Confirmation of the Quantitative Data}

The recommendations made by the participants (Figure 1), are basically suggestions on actions that should be performed by the teacher. Said actions can be inferred to derive from the principles that guide the teacher's practice and which they considered to be positive. Moreover, those principles can be interpreted as an implicit use of the DSC (or of any of its components or indicators). Those principles which guide the action can also be interpreted as dispositions towards the action that derives from a group of beliefs that form the participants' conceptions, as was observed in the previous analysis. In such conception, the presence of the DSC is inferred, meaning a coherent result was obtained when performing a quantitative analysis. Additionally, this agrees with the results existing in the literature, which highlight good practices when using robots in the classroom, especially in: (a) collaborative work, through active and continuous learning considering the profile of the students; (b) the motivation, according to the profile of the students of the training experience, where robotics helps personalized learning; (c) the use of suitable materials; (d) the teachers' training for a didactic innovation that begins with the planning, the articulation of strategies of the moments in which the use of robots is integrated along with the process of evaluating its incorporation in the classroom [31,32].

As it was observed in the above-described exploratory analysis, the average scores that the participants gave to their valuations for the closed questions questionnaire were bigger for learning ( 4.5 points) than for teaching ( 4.2 points). This result is coherent with the benefits that the participants give to their answers for the second open question (Figure 2) about the use of robots in the classroom: essentially, more learning (cognitive suitability criterion) and more motivation (affective suitability criterion) which both are more directly related to the learning dimension than to the teaching dimension.

Additionally, though all the categories analyzed (criterions) from both dimensions (learning and teaching) allowed to conclude positive conceptions about the use of robots in math classes during the early years of school, above the three points (of indifference), it was observed that the mediational suitability criterion in the teaching dimension obtained the lowest score (3.5 points). In this sense, the qualitative data allowed us to confirm this result, specifically in the data reported in Figure 3, since the negative scores to the statements related to this category were the ones referring to the high number of students and the reduced space in the classrooms, which complicates the teamwork.

\section{Conclusions}

In this study, the results which allowed to characterize the conceptions of primary school teachers regarding the impact of the use of robotics in Mathematics were presented. The sample used consisted of 83 Chilean primary school teachers (for First to Fourth grades).

To begin with, it was convenient to identify professional profiles according to relevant characteristics of the participants' professional experience and academic formation; after a group analysis, three different clusters or groups were identified, with similar characteristics among them (Table 4$)$. The first cluster consisted of 54 (65.1\%) subjects, whereas the second was formed by $19(22.9 \%)$ and the third by $10(12.0 \%)$. In all the cases, there were a predominance of women (as well as globally), whereas the academic formation was in most of the cases a postgraduate degree in math in Clusters 1 and 2, and a master's degree in Cluster 3. As for professional experience, in all the groups the participants had in their majority more than three years of experience, mainly in Second, Fourth and First grades for Clusters 1, 2 and 3, respectively.

Secondly, the conceptions of the teachers about the use of pedagogical robots in the learning and teaching mathematics' process were explored. Among the global results, it can be concluded that the participants have conceptions that entails positive dispositions about the introduction of robots for teaching mathematics. Additionally, their conceptions are positive towards the advantages of the use of robots for learning mathematics, although 
slightly less positive regarding teaching mathematics with robots. This being a result consistent with other studies [34,35,37].

In turn, the results shown that these conceptions are complex, and in them the presence, in a bigger or lesser scale, of the six DSC can be inferred, more evidently in the qualitative analysis (Figures 1-3) than in the quantitative one. In relation to that result, it can be objected that it was foreseeable, considering the fact of how the items in the questionnaire were presented. Nonetheless, it can also be considered that the teaching and learning processes are very complex because several factors intervene in them (affective aspects, management of the classroom, use of the resources, learning evaluation, among others); therefore, it is typical that the conceptions are a broad group of beliefs, as suggested by several investigators, i.e., D'Amore and Fandiño [48], and that some of them can even conflict according to the context in which the process of learning and teaching takes place. This has also been observed in other studies $[48,58,59]$.

A relevant matter is to question what the relation among the group of teachers and their conceptions is. In Cluster 1, the conceptions were highly positive in every suitability criterion in terms of learning and teaching mathematics with robots. In Cluster 2, the conceptions were also positive, but less intense than in cluster 1 . In this case, an indifferent position in respect of the adequation of the robotic material resources when teaching mathematics was observed, but this was positive in terms of its learning. In Cluster 3, the conceptions were, in general, negative; in the other cases, the criterion with a lower average score was the mediational one regarding the use of robots for teaching math. As for the qualitative data, they confirm these results providing more information since the participants' discourse acknowledges that the difficulties to implement the use of robots are related to the high number of students in their classrooms and the reduced space for teamwork.

In turn, in the search of relations among the conceptions of the use of robots when teaching and learning mathematics according to the participants' previous experience and the academic formation, it could be observed, after implementing the independent chi-squared test, that the scores of the variables analyzed as for the academic formation (postgraduate degree, master's or courses) and the previous experience (in years) are independent from the participants' conceptions towards the use of robots for teaching and learning mathematics. However, although weak and non-relevant, some empirical correlations reflect a certain degree of negative association among the conceptions towards teaching and the participants' years of experience.

Finally, these results can be very useful as guidance for the development of stages of training and professional formation of primary school teachers so that robotic resources can be incorporated in the teaching and learning processes of mathematics, since these results show the complexity of factors that must be considered when introducing the use of robots in the classrooms.

Supplementary Materials: The following are available online at https:/ /www.mdpi.com/article/10 $.3390 /$ math $9243186 / \mathrm{s} 1$, Annex 1: Items presented in the online questionnaire.

Author Contributions: Conceptualization, M.J.S., A.B. and V.F.; methodology, M.J.S.; data preprocessing, M.J.S.; data validation, A.B., V.F. and C.V.; writing-original draft preparation, review, and editing, M.J.S., A.B., V.F. and C.V.; project administration, funding acquisition, M.J.S. All authors have read and agreed to the published version of the manuscript.

Funding: This research was funded by the Fondecyt research project $\mathrm{N}^{\circ} 11190547$ and the Spanish R\&D project PGC2018-098603-B-I00 (MCIU/AEI/FEDER, UE).

Institutional Review Board Statement: The study was carried out in accordance with the guidelines of the Declaration of Helsinki, and was approved by the Ethics Committee of the Catholic University of Maule ( $\mathrm{N}^{\circ} 113,23$ June 2020).

Informed Consent Statement: Informed consent was obtained from all subjects involved in the study.

Data Availability Statement: The data is not publicly available due to ethical requirements. 
Conflicts of Interest: The authors declare no conflict of interest.

\section{References}

1. Guzmán, A. El Enfoque de Métodos Mixtos: Una Nueva Metodología en la Investigación Educatica; Idea Editorial: Santa Cruz de Tenerife, Spain, 2015.

2. Ponte, J.P. Concepções dos Professores de Matemática e Processos de Formação. In Educação Matemática: Temas de Investigação; Ponte, J.P., Ed.; Instituto de Inovação Educacional: Lisboa, Portugal, 1992; pp. 185-239.

3. Guimarães, H. Ensinar Matemática: Concepções e Práticas. Master's Thesis, DEFCUL, Lisboa, Portugal, 1988.

4. Loureiro, M.C. Calculadoras na Educação Matemática: Uma Experiência na Formação de Professores. Master's Thesis, DEFCUL, Lisboa, Portugal, 1991.

5. Ponte, J.P.; Carreira, S. Spreadsheet and investigative activities: A case study of an innovative experience. In New Information Technologies and Mathematical Problem Solving: Research in Contexts of Practice; Ponte, J., Matos, J.F., Matos, J.M., Fernandes, D., Eds.; Springer: Berlin, Germany, 1992.

6. Thompson, A.G. Teachers' Conceptions of Mathematics and Mathematics Teaching: Three Case Studies. Unpublished. Doctoral Dissertation, Universidade da Georgia, Athens, GA, USA, 1982.

7. Moreano, G.; Asmad, U.; Cruz, G.; Cuglievan, G. Concepciones sobre la enseñanza de matemática en docentes de primaria de escuelas estatales. Rev. Psicol. 2008, 26, 299-334. [CrossRef]

8. Feiman-Nemser, S.; Floden, R. The cultures of teaching. In Handbook of Research on Teaching, 3rd ed.; Wittrock, M.C., Ed.; Macmillan: New York, NY, USA, 1986.

9. Thompson, A. Teacher's beliefs and conceptions: A synthesis of the research. In Handbook of Research on Mathematics Learning and Teaching; Grouws, D.A., Ed.; Macmillan: New York, NY, USA, 1992; pp. 127-146.

10. Moreno, M.M.; Azcárate, C. Concepciones y creencias de los profesores universitarios de matemáticas acerca de la enseñanza de las ecuaciones diferenciales. Enseñanza Cienc. Rev. Investig. Exp. Didácticas 2003, 21, 265-280. [CrossRef]

11. Martínez Silva, M.; Gorgorió i Solá, N. Concepciones Sobre la Enseñanza de la Resta: Un Estudio en el ámbito de la Formación Permanente del Profesorado. Rev. Electrónica Investig. Educ. 2004, 6. Available online: https://redie.uabc.mx/redie/article/view/ 93/ (accessed on 3 October 2021).

12. Abrantes, P. Porque se Ensina Matemática: Perspectivas e Concepções de Professores e Futuros Professores; (Provas APCC); DEFCUL: Lisboa, Portugal, 1986.

13. Fey, J.T. Mathematics teaching today: Perspectives from three national surveys. Math. Teach. 1978, 72, 490-504. [CrossRef]

14. Dolores, C.; García, J. Concepciones de Profesores de Matemáticas sobre la Evaluación y las Competencias. Números Rev. Didáctica Matemáticas 2016, 92, 71-92.

15. Bedoya, M.M.; Ospina, S.A. Concepciones que Poseen los Profesores de Matemática Sobre la Resolución de Problemas y Cómo Afectan los Métodos de Enseñanza y Aprendizaje. Ph.D. Thesis, Maestría en Educación Matemática, Universidad de Medellín, Medellín, Colombia, 2014.

16. Contreras, L.C.; Carrillo, J. Diversas concepciones sobre resolución de problemas en el aula. Educ. Matemática 1998, 10 , 26-37.

17. Trejo, E.; Camarena, P. Concepciones de los profesores y su impacto en la enseñanza de un sistema de ecuaciones lineales con dos incógnitas. In Acta Latinoamericana de Matemática Educativa; Patricia, L., Ed.; Comité Latinoamericano de Matemática Educativa: México, DF, Mexico, 2011; pp. 1095-1103.

18. Franco, A.M.; Canavarro, A.P. Atitudes dos Professores Face à Resolução de Problemas; APM: Lisboa, Portugal, 1987.

19. Silva, A. A Calculadora No Percurso de Formação de Professoras de Matemática. Master's Thesis, DEFCUL, Lisboa, Portugal, 1991.

20. Veloso, M.G. Novas Tecnologias de Informação: Um Programa de Formação de Professores de Matemática. Master's Thesis, DEFCUL, Lisboa, Portugal, 1991.

21. Ribeiro, M.J.B.; Ponte, J.P. A formação em novas tecnologias e as concepções e práticas dos professores de Matemática. Quadrante 2000, 9, 3-26.

22. Wachira, P.; Keengwe, J.; Onchwari, G. Mathematics preservice teachers' beliefs and conceptions of appropriate technology use. AACE J. 2008, 16, 293-306.

23. McGinnis, J.R.; Hestness, E.; Mills, K.; Ketelhut, D.; Cabrera, L.; Jeong, H. Preservice science teachers' beliefs about computational thinking following a curricular module within an elementary science methods course. Contemp. Issues Technol. Teach. Educ. 2020, 20, 85-107.

24. Sullivan, F.R.; Moriarty, M.A. Robotics and Discovery Learning: Pedagogical Beliefs, Teacher Practice, and Technology Integration. J. Technol. Teach. Educ. 2009, 17, 109-142. Available online: https://www.learntechlib.org/primary/p/26177/ (accessed on 3 October 2021).

25. Bouchaib, F.; Hanane, N. Pedagogical Robotics-A Way to Experiment and Innovate in Educational Teaching in Morocco. Int. J. Educ. Learn. Syst. 2017, 2, 71-75.

26. Tang, A.L.; Tung, V.W.S.; Cheng, T.O. Dual roles of educational robotics in management education: Pedagogical means and learning outcomes. Educ. Inf. Technol. 2020, 25, 1271-1283. [CrossRef]

27. Yang, Y.; Long, Y.; Sun, D.; Van Aalst, J.; Cheng, S. Fostering students' creativity via educational robotics: An investigation of teachers' pedagogical practices based on teacher interviews. Br. J. Educ. Technol. 2020, 51, 1826-1842. [CrossRef] 
28. Casey, J.E.; Pennington, L.K.; Mireles, S.V. Technology Acceptance Model: Assessing Preservice Teachers' Acceptance of FloorRobots as a Useful Pedagogical Tool. Tech. Know. Learn. 2021, 26, 499-514. [CrossRef]

29. Kennedy, J.; Lemaignan, S.; Belpaeme, T. The Cautious Attitude of Teachers towards Social Robots in Schools. In Robots 4 Learning Workshop at IEEE RO-MAN; 2016. Available online: https://core.ac.uk/download/pdf/84595376.pdf (accessed on 3 October 2021).

30. Jormanainen, I.; Zhang, Y.; Kinshuk, K.; Sutinen, E. Pedagogical Agents for Teacher Intervention in Educational Robotics Classes: Implementation Issues. In Proceedings of the 2007 First IEEE International Workshop on Digital Game and Intelligent Toy Enhanced Learning (DIGITEL'07), Jhongli, Taiwan, 26-28 March 2007; pp. 49-56. Available online: https:/ /ieeexplore.ieee.org/ abstract/document/4148831 (accessed on 3 October 2021).

31. Ribeiro, C.; Coutinho, C.; Costa, M.F. Educational Robotics as a Pedagogical Tool for Approaching Problem Solving Skills in Mathematics within Elementary Education. In Proceedings of the 6th Iberian Conference on Information Systems and Technologies (CISTI 2011), Chaves, Portugal, 15-18 June 2011; pp. 1-6. Available online: https: / ieeexplore.ieee.org/abstract/ document/5974210 (accessed on 3 October 2021).

32. Schina, D.; Esteve-González, V.; Usart, M. An overview of teacher training programs in educational robotics: Characteristics, best practices and recommendations. Educ. Inf. Technol. 2021, 26, 2831-2852. [CrossRef]

33. Scaradozzi, D.; Screpanti, L.; Cesaretti, L.; Storti, M.; Mazzieri, E. Implementation and Assessment Methodologies of Teachers' Training Courses for STEM Activities. Tech. Know. Learn. 2019, 24, 247-268. [CrossRef]

34. Lopez-Caudana, E.; Ramirez-Montoya, M.S.; Martínez-Pérez, S.; Rodríguez-Abitia, G. Using Robotics to Enhance Active Learning in Mathematics: A Multi-Scenario Study. Mathematics 2020, 8, 2163. [CrossRef]

35. González, Y.A.C.; Muñoz-Repiso, A.G.V. A Robotics-Based Approach to Foster Programming Skills and Computational Thinking: Pilot Experience in the Classroom of Early Childhood Education. In Proceedings of the Sixth International Conference on Technological Ecosystems for Enhancing Multiculturality, Salamanca, Spain, 24-26 October 2018; pp. 41-45. Available online: https: / / dl.acm.org/doi/abs/10.1145/3284179.3284188 (accessed on 3 October 2021).

36. Schina, D.; Esteve-Gonzalez, V.; Usart, M. Teachers' Perceptions of Bee-Bot Robotic Toy and Their Ability to Integrate It in Their Teaching. In Robotics in Education; Lepuschitz, W., Merdan, M., Koppensteiner, G., Balogh, R., Obdržálek, D., Eds.; Advances in Intelligent Systems and Computing; Springer: Cham, Switzerland, 2021; Volume 1316. [CrossRef]

37. Papadakis, S. Robots and Robotics Kits for Early Childhood and First School Age. International Association of Online Engineering. 2020. Available online: https:/ /www.learntechlib.org/p/218338/ (accessed on 3 October 2021).

38. Seckel, M.J.; Vásquez, C.; Samuel, M.; Breda, A. Errors of programming and ownership of the Robot concept made by Trainee Kindergarten Teachers during an induction training. Educ. Inf. Technol. 2021. [CrossRef]

39. Godino, J.D.; Batanero, C.; Font, V. The onto-semiotic approach: Implications for the prescriptive character of didactics. Learn. Math. 2019, 39, 37-42.

40. NCTM. Principles and Standards for School Mathematics; VA and National Council of Teachers of Mathematics: Reston, VA, USA, 2000.

41. Breda, A.; Pino-Fan, L.R.; Font, V. Meta didactic-mathematical knowledge of teachers: Criteria for the reflection and assessment on teaching practice. EURASIA J. Math. Sci. Technol. Educ. 2017, 13, 1893-1918. [CrossRef]

42. Sánchez, A.; Font, V.; Breda, A. Significance of creativity and its development in mathematics classes for preservice teachers who are not trained to develop students' creativity. Math. Educ. Res. J. 2021, 13, 31-51. [CrossRef]

43. Godino, J.D. Indicadores de la idoneidad didáctica de procesos de enseñanza y aprendizaje de las matemáticas. Cuad. Investig. Form. Educ. Matemática 2013, 8, 111-132.

44. Breda, A. Características del análisis didáctico realizado por profesores para justificar la mejora en la enseñanza de las matemáticas Bolema 2020, 34, 69-88. [CrossRef]

45. Breda, A.; Font, V.; Pino-Fan, L.R. Criterios valorativos y normativos en la didáctica de las matemáticas: El caso del constructo idoneidad didáctica. Bolema 2018, 32, 255-278. [CrossRef]

46. Peirce, C.S. The Fixation of Belief, Popular Science Monthly 12, 1-15 November 1877. Available online: http:/ /www.bocc.ubi.pt/ pag/peirce-charles-fixation-belief.pdf (accessed on 3 October 2021).

47. D'Amore, B.; Fandiño, M.I. Cambios de convicciones en futuros profesores de matemáticas de la Escuela Secundaria Superior. Epsil. Rev. Soc. Andal. Educ. Matemática Thales 2004, 58, 23-44.

48. Ramos, A.B. Objetos Personales, Matemáticos y Didácticos, del Profesorado y Cambios Institucionales. El Caso de la Contextualización de las Funciones en una Facultad de Ciencias Económicas y Sociales. Tesis Doctoral No Publicada, Universitat de Barcelona, Barcelona, Spain, 2006.

49. Breda, A.; Seckel, M.J.; Farsani, D.; Silva, J.F.; Calle, E. Teaching and learning of mathematics and criteria for its improvement from the perspective of future teachers: A view from the Ontosemiotic Approach. Math. Teach. Res. J. 2021, 13, 31-51.

50. Garcés, W. Criterios que Orientan la Práctica del Profesor Para Explicar Matemáticas en un Curso de Ciències Básicas en Carreras de Ingeniería en el Perú: El Caso de la Derivada. Tesis Doctoral No Publicada, Universitat de Barcelona,, Barcelona, Spain, 2021.

51. Hummes, V.B.; Font, V.; Breda, A. Combined Use of the Lesson Study and the Criteria of Didactical Suitability for the Development of the Reflection on the own Practice in the Training of Mathematics Teachers. Acta Sci. 2019, 21, 64-82. [CrossRef]

52. Fernández-Morales, K.; Vallejo, A.; Ojeda, M.; y McAnally-Salas, L. Evaluación psicométrica de un instrumento para medir la apropiación tecnológica de estudiantes universitarios. Rev. Electrónica Psicol. Iztacala 2015, 18, $286-306$. 
53. Hernández, R.; Fernández, C.; Baptista, P. Metodología de la Investigación, 6th ed.; McGraw-Hill: Ciudad de México, Mexico, 2014.

54. Hernández-Nieto, R. Instrumentos de Recolección de Datos en Ciencias Sociales y Ciencias Biomédicas; Universidad de los Andes: Mérida, Venezuela, 2011.

55. Seckel, M.J.; Breda, A.; Sánchez, A.; Font, V. Criterios asumidos por profesores cuando argumentan sobre la creatividad matemática. Educ. Pesqui. 2019, 45, e211926. [CrossRef]

56. Bisquerra, R. Metodología de la Educación Educativa, 6th ed.; La Muralla: Madrid, Spain, 2016.

57. Latorre, A. La Investigación-Acción. Conocer y Cambiar la Práctica Educativa, 2nd ed.; Graou: Barcelona, Spain, 2004.

58. Ramos, A.B.; Font, V. Criterios de idoneidad y valoración de cambios en el proceso de instrucción matemática. Rev. Latinoam. Investig. Matemática Educ. 2008, 11, 233-265.

59. Hummes, V.; Sol, T.; Breda, A. Argumentación práctica sobre el Teorema de Pitágoras por profesores de matemáticas en un curso de formación. In Investigación en Educación Matemática XXIV; Diago, P.D., Yáñez, D.F., González-Astudillo, M.T., Carrillo, D., Eds.; SEIEM: Valencia, Spain, 2021; pp. 343-350. 